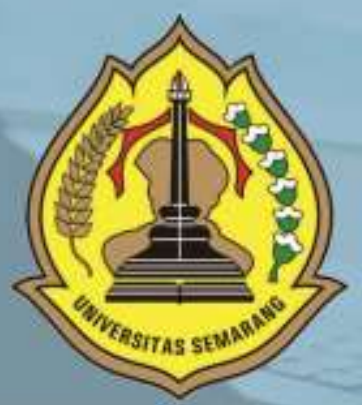

P-ISSN: 1412-5331, E-ISSN: 2716-2532 MAJALAH ILMIAH FAKULTAS EKONOMI UNIVERSITAS SEMARANG

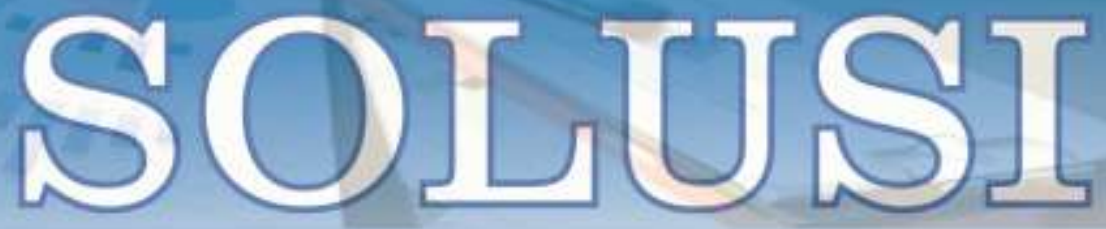

PENGARUH TINGKAT LITERASI KEUANGAN, SIKAP INDIVIDU TERHADAP MINAT INVESTASI SAHAM DI KALANGAN MAHASISWA S2 MAGISTER MANAJEMEN UNIVERSITAS SEMARANG (Asah Wiari Sidiq: Asih Niati - Universitas Semarang)

PENINGKATAN KINERJA PENGAJARAN DOSEN MELALUI KEPEMIMPINAN TRANSFORMASIONAL DAN PEMENUHAN KEBUTUHAN PSIKOLOGIS DASAR DENGAN PEMEDIASI MOTIVASI KER.JA (Anik Herminingsih - Universitas Mercu Buana)

PENGARUH PAJAK, TUNNELING INCENTIVE DAN GOOD CORPORATE GOVERNANCE (GCG) DAN MEKANISME BONUS TERHADAP INDIKASI TRANSFER PRICING PADA PERUSAHAAN MANUFAKTUR (Arum Sasi Andayani; Andiani Ika Sulistyanuati - Liniversitas Semarang)

PENGELOLAAN ALOKASI DANA DESA: AKUNTABILITAS DAN TRANSPARANSI (STUDI KASUS PADA DESA GINGGANGTANI, KECAMATAN GUBUG, KABUPATEN GROBOGAN) (Ana Rokhatt: Saifidin: Dian Trivani - Universitas Semarang)

PENERAPAN STRATEGI BAURAN PEMASARAN PADA USAHA KECIL TELUR ASIN DI KELURAHAN TEGAL SARI, KECAMATAN CANDI SARI, SEMARANG (Nisa Novia Avien Christy; Dwi Widi Pratito - Universitas Semarang)

FAKTOR-FAKTOR YANG MEMPENGARUHI PROFITABILITAS LEMBAGA PERKREDITAN DESA (LPD) DI KABUPATEN BADUNG (Ida Ayu Nyoman Yuliastuti, Putu Kepramareni, I Gusti Ayu Asta Yunisari - Universitas Mahasaraswati Denpasar)

KEBERHASILAN MEMPERTAHANKAN WARUNG MAKAN PRASMANAN MBAH SAN (Sri Wulandari: Susanto - Universitas Semarang)

BRAND PERSONALITY DAN GENDER BRAND PERSONALITY STRATEGI MEMBANGUN MEREK (Haris Murwanto - Universitas Semarang)

POLA PERMINTAN DAN PENAWARAN KETERSEDIAAN DAGING SAPI NASIONAL TAHUN 2030 DENGAN PENDEKATAN FORECASTING (Moeljono - Universitas Semarang)

PENGARUH BRAND IMAGE, KUALITAS PRODUK, PERSEPSI HARGA TERHADAP KEPUTUSAN PEMBELIAN (STUDI KASUS PADA PRODUK SUSU NATURSOYA CV. GLOBAL MANDIRI SEJAHTERA KANCA PURWODADI)

(Ajeng Ayr Fatimah P: Soedarmadi - Untversitas Semarang) 


\section{DESKRIPSI}

Majalah IImiah Solusi Mengkaji

Masalah-Masalah Sosial,

Ekonomi dan Bisnis

\section{KETERANGAN TERBIT}

Terbit Pertama Kali Juli 2002

dan SelanjutnyaTerbit Tiga Bulan

Sekali (Januari, April, Juli dan

Oktober)

\section{PENERBIT}

Fakultas Ekonomi USM

\section{ALAMAT PENERBIT}

JL. Soekarno Hatta Semarang

Telp. 024-6702757 Fax. 024-6702272

\section{PENGELOLA}

Editor in Chief : Yohanes Suhardjo, SE, M.Si., Ak, CA Vice Editor Chief : Sugeng Rianto, SE, MM

Managing Editor: Edy Suryawardana, SE, MM

Secretary of Managing Editor : Asih Niati, SE, MM

Administration \& Circulation :

Citra Rizkiana, SE, MM

Layout \& Typesetting : M Burhan Hanif S.Kom, M.Kom

Board of Editors:

1. Prof. Dr. Ir. Kesi Widjajanti, SE, MM (USM)

2. Prof. Drs. Mohammad Nasir, Msi, Ph.D, AK. (USM)

3. Prof. Supramono SE, MBA, DBA (UKSW)

4. Prof. Drs. H. Imam Ghozali, M.Com, Akt, PhD (UNDIP)

5. Prof. Dr. Agus Suroso, MS (UNSOED)

6. Prof. Dr. Widodo, SE, M.Si (UNISSULA)

7. Prof. Dr. Dra. Sulastri, ME, M.Kom (UNSRI)

8. Dr. Ardiani Ika S, SE, MM, Ak, CA, CPA (USM)

\section{KATA PENGANTAR}

Sungguh merupakan kebahagiaan tersendiri bagi kami, takala kami dapat hadir rutin setiap tiga bulan sekali untuk saling bertukar pikiran mengenai hal-hal baru dibidang sosial, ekonomi dan bisnis.

Pada kesempatan ini penerbit menyampaikan terima kasih kepada semua pihak yang telah mengirimkan artikel-artikelnya. Penerbit akan membuka kesempatan seluas-luasnya bagi seluruh kalangan akademisi maupun praktisi baik dari dalam maupun luar Universitas Semarang untuk mempublikasikan karya ilmiahnya.

Penerbitan majalah ilmiah "SOLUSI" kali ini menghadirkan 10 (Sepuluh) artikel yang kami anggap layak untuk diterbitkan, dengan harapan dapat menjadi tambahan referensi bagi para pembaca dan menjadi sumbangan pengembangan persemaian khasanah pengetahuan dibidang sosial, ekonomi dan bisnis.

Akhir kata semoga majalah ilmiah "SOLUSI" dapat memberi manfaat yang sebesar-besarnya.

Hormat Kami 


\section{DAFTAR ISI}

PENGARUH TINGKAT LITERASI KEUANGAN, SIKAP INDIVIDU

TERHADAP MINAT INVESTASI SAHAM DI KALANGAN MAHASISWA S2 MAGISTER MANAJEMEN UNIVERSITAS SEMARANG

(Asah Wiari Sidiq; Asih Niati - Universitas Semarang).......

PENINGKATAN KINERJA PENGAJARAN DOSEN MELALUI

KEPEMIMPINAN TRANSFORMASIONAL DAN PEMENUHAN KEBUTUHAN PSIKOLOGIS DASAR DENGAN PEMEDIASI MOTIVASI KERJA

(Anik Herminingsih - Universitas Mercu Buana)

PENGARUH PAJAK, TUNNELING INCENTIVE DAN GOOD CORPORATE GOVERNANCE (GCG) DAN MEKANISME BONUS TERHADAP INDIKASI TRANSFER PRICING PADA PERUSAHAAN MANUFAKTUR

(Arum Sasi Andayani; Ardiani Ika Sulistyawati - Universitas Semarang)

PENGELOLAAN ALOKASI DANA DESA: AKUNTABILITAS DAN TRANSPARANSI

(STUDI KASUS PADA DESA GINGGANGTANI, KECAMATAN GUBUG, KABUPATEN GROBOGAN)

(Ana Rokhati; Saifudin; Dian Triyani - Universitas Semarang).

PENERAPAN STRATEGI BAURAN PEMASARAN PADA USAHA KECIL TELUR ASIN DI KELURAHAN TEGAL SARI, KECAMATAN CANDI SARI, SEMARANG

(Nisa Novia Avien Christy; Dwi Widi Pratito - Universitas Semarang)

FAKTOR-FAKTOR YANG MEMPENGARUHI PROFITABILITAS LEMBAGA PERKREDITAN DESA (LPD) DI KABUPATEN BADUNG

(Ida Ayu Nyoman Yuliastuti; Putu Kepramareni; I Gusti Ayu Asta Yunisari - Universitas Mahasaraswati Denpasar)..... .75

KEBERHASILAN MEMPERTAHANKAN WARUNG MAKAN PRASMANAN MBAH SAN

(Sri Wulandari; Susanto - Universitas Semarang).....

BRAND PERSONALITY DAN GENDER BRAND PERSONALITY STRATEGI MEMBANGUN MEREK

(Haris Murwanto - Universitas Semarang).

POLA PERMINTAN DAN PENAWARAN KETERSEDIAAN DAGING SAPI NASIONAL TAHUN 2030 DENGAN PENDEKATAN FORECASTING

(Moeljono - Universitas Semarang)......

PENGARUH BRAND IMAGE, KUALITAS PRODUK, PERSEPSI HARGA TERHADAP KEPUTUSAN PEMBELIAN (STUDI KASUS PADA PRODUK SUSU NATURSOYA CV. GLOBAL MANDIRI SEJAHTERA KANCA PURWODADI)

(Ajeng Ayu Fatimah P; Soedarmadi - Universitas Semarang) 


\title{
FAKTOR-FAKTOR YANG MEMPENGARUHI PROFITABILITAS LEMBAGA PERKREDITAN DESA (LPD) DI KABUPATEN BADUNG
}

\author{
Ida Ayu Nyoman Yuliastuti ${ }^{1}$ \\ Putu Kepramareni ${ }^{2}$ \\ I Gusti Ayu Asta Yunisari ${ }^{3}$ \\ ia.yuliastuti.@unmas.ac.id ${ }^{1}$ \\ pkepramareni@yahoo.co.id ${ }^{2}$ \\ gekyuni17@gmail.com ${ }^{3}$
}

Fakultas Ekonomi dan Bisnis Universitas Mahasaraswati Denpasar

Diterima: November 2019, Disetujui:Desember 2019,Dipublikasikan: Januari 2020

\begin{abstract}
Lembaga Perkreditan Desa are non-bank microfinance institutions owned by the Desa Adat or Desa Pekraman Bali. LPD is a business entity whose activities are collecting public funds in the form of deposits and channeling them back in the form of credit. Profitability is an indicator to assess whether the LPD management's financial performance is good or bad in generating profits. This study aims to determine the effect of cash turnover, credit risk, loan to deposit ratio, bopo on profitability.

This study uses secondary data in the form of LPD financial reports in Badung Regency for the period of 2016-2018. The population in this study is the LPD in Badung Regency which is registered in the LPLPD totaling 122 LPD. The sampling method uses purposive sampling with a sample of 102 LPD. Data analysis techniques using Multiple Linear Regression Analysis.

The results showed that cash turnover and credit risk had no effect on LPD profitability in Badung Regency. Another result was found that the loan to deposit ratio had a positive effect on LPD profitability in Badung Regency, while bopo had a negative effect on LPD profitability in Badung Regency.
\end{abstract}

Keywords: Cash Turnover, Credit Risk, Loan to Deposit Ratio, Bopo, Profitability

\begin{abstract}
ABSTRAK
Lembaga Perkreditan Desa adalah lembaga keuangan mikro non-bank yang dimiliki oleh desa adat atau desa pekraman di Bali. LPD adalah badan usaha yang kegiatannya mengumpulkan dana publik dalam bentuk simpanan dan menyalurkannya kembali dalam bentuk kredit. Profitabilitas adalah indikator untuk menilai apakah kinerja keuangan manajemen LPD baik atau buruk dalam menghasilkan laba. Penelitian ini bertujuan untuk mengetahui pengaruh cash turnover, risiko kredit, loan to deposit ratio, bopo terhadap profitabilitas.

Penelitian ini menggunakan data sekunder berupa laporan keuangan LPD di Kabupaten Badung untuk periode 2016-2018. Populasi dalam penelitian ini adalah LPD di Kabupaten Badung yang terdaftar di LPLPD berjumlah 122 LPD. Metode pengambilan sampel menggunakan purposive sampling dengan sampel 102 LPD. Teknik analisis data menggunakan Analisis Regresi Linier Berganda.

Hasil penelitian menunjukkan bahwa cash turnover dan risiko kredit tidak berpengaruh terhadap profitabilitas LPD di Kabupaten Badung. Hasil lainnya didapat bahwa loan to deposit ratio berpengaruh positif terhadap profitabilitas LPD di Kabupaten Badung, sedangkan bopo berpengaruh negatif terhadap profitabilitas LPD di Kabupaten Badung.
\end{abstract}

Kata kunci: $\quad$ Perputaran Kas, Risiko Kredit, Rasio Loan to Deposit, Bopo, Profitabilitas 


\section{PENDAHULUAN}

\section{Latar Belakang Masalah}

Lembaga Perkreditan Desa (LPD) merupakan lembaga keuangan mikro nonbank yang dimiliki oleh Desa Adat atau Desa Pekraman Bali. Berdasarkan Peraturan Gubernur Bali Nomor 11 Tahun 2013, LPD adalah lembaga keuangan milik desa pakraman yang melakukan segala kegiatan di lingkungan desa pakraman dan untuk krama desa. Fungsi dan tujuan LPD adalah untuk memberikan kesempatan berusaha bagi para warga desa, untuk menampung tenaga kerja yang ada di pedesaan, serta melancarkan lalu lintas pembayaran, sekaligus menghapuskan keberadaan lintah darat.

Profitabilitas menjadi indikator untuk menilai baik buruknya kinerja dari sebuah perusahaan dalam menjalankan kegiatan bisnisnya untuk menghasilkan profitabilitas yang optimal. Profitabilitas merupakan kemampuan perusahaan dengan memperoleh laba dalam hubungannya dengan penjualan, total aktiva maupun modal sendiri (Sartono, 2010:122). Munawir (2010:33) menyatakan bahwa profitabilitas menunjukan kemampuan perusahaan untuk menghasilkan laba selama periode tertentu dengan jumlah aktiva atau jumlah modal perusahaan tersebut.

Cash turnover (tingkat perputaran kas) merupakan perbandingan antara penjualan dengan jumlah kas rata-rata, perputaran kas menunjukkan kemampuan kas dalam menghasilkan pendapatan sehingga dapat dilihat berapa kali uang kas berputardalam satu periode tertentu (Kasmir, 2015:140-141). Penjualan pada lembaga perkreditan yang dimaksud adalah total pendapatan bunga. Efisiensi penggunaan kas dalam perusahaan dapat dilihat melaui besar kecilnya perputaran kas.

Risiko kredit merupakan risiko yang wajar terjadi mengingat salah satu usaha inti LPD itu sendiri adalah pemberian kredit. Kredit macet atau bermasalah yang terjadi secara tiba-tiba tanpa dimulai serangkaian tanda-tanda atau sinyal adalah sangat langka. Bank dapat mendeteksi dari variabel-variabel dalam penepatan kolektibilitas yang didasarkan pada kriteria tunggakan utang pokok dan bunga dan cerukan (overdraft), indikator lainnya.

Loan to Deposit Ratio (LDR) merupakan salah satu cara untuk menghitung tingkat kredit yang disalurkan. Semakin besar jumlah dana yang disalurkan kepada nasabah dalam bentuk kredit maka jumlah dana yang menganggur berkurang dan penghasilan bunga yang diperoleh akan meningkat. Loan to Deposit Ratio (LDR) dapat 
diartikan sebagai kemampuan perusahaan dalam memenuhi kewajibannya yang segera harus dibayar (Taswan, 2010:246).

BOPO merupakan perbandingan antara total biaya dan total pendapatan operasional (Bambang S, 2010). Beban operasional dan pendapatan operasional merupakan perbandingan antara biaya operasional dengan pendapatan operasional dalam mengukur tingkat efisiensi LPD dalam kegiatan operasionalnya.

\section{Rumusan Masalah}

Berdasarkan latar belakang yang telah diuraikan diatas, maka rumusan masalah penelitian ini adalah sebagai berikut : Apakah cash turnover berpengaruh terhadap profitabilitas LPD di Kabupaten Badung? Apakah risiko kredit berpengaruh terhadap profitabilitas LPD di Kabupaten Badung? Apakah loan to deposit ratio berpengaruh terhadap profitabilitas LPD di Kabupaten Badung ? Apakah BOPO berpengaruh terhadap profitabilitas LPD di Kabupaten Badung ?

\section{LANDASAN TEORI}

\section{Teori Sinyal (Signalling Theory)}

Menurut Brigham dan Houston (2011: 184) teori sinyal adalah suatu tindakan yang diambil oleh manajemen perusahaan yang memberikan petunjuk bagi investor tentang bagaimana manajemen memandang prospek perusahaan. Teori sinyal menjelaskan mengapa perusahaan mempunyai dorongan untuk memberikan informasi laporan keuangan pada pihak eksternal.

\section{Laporan keuangan}

Laporan keuangan merupakan suatu informasi yang menggambarkan kondisi suatu perusahaan dimana selanjutnya itu akan menjadi suatu informasi yang menggambarkan kinerja suatu perusahaan. (Fahmi, 2012: 22). Ikatan Akuntan Indonesia (2012:5) mengemukakan laporan keuangan merupakan struktur yang menyajikan posisi keuangan dan kinerja keuangan dalam sebuah entitas. Tujuan utama laporan keuangan adalah penyajian informasi mengenai posisi keuangan, kinerja keuangan dan arus kas dari entitas yang sangat berguna untuk membuat keputusan ekonomi bagi para penggunnya. 


\section{Profitabilitas}

Profitabilitas merupakan pengukur kemampuan perusahaan dalam memperoleh laba dan untuk menilai kinerja suatu perusahaan. Profitabilitas menurut Sudana (2011:22) adalah kemampuan perusahaan untuk menghasilkan laba dengan menggunakan sumber-sumber yang dimiliki seperti aktiva modal atau penjualan perusahaan.

\section{Cash Turnover}

Rasio perputaran kas (Cash Turnover) digunakan untuk mengukur tingkat kecukupan modal kerja perusahaan yang dibutuhkan untuk membayar tagihan dan membiayai penjualan. Menurut Riyanto (2011 : 95) bahwa: "Perputaran kas adalah perbandingan antara penjualan dengan jumlah kas rata-rata".Jumlah kas dapat pula dihubungkan dengan jumlah penjualan atau salesnya.

\section{Risiko Kredit}

Risiko kredit merupakan risiko yang wajar terjadi mengingat salah satu usaha inti LPD itu sendiri adalah pemberian kredit. Sebelum memberikan kredit, LPD harus mengumpulkan informasi yang memadai tentang pelanggan potensial untuk dapat meminimalisir risiko kredit yang akan dihadapi di kemudian hari, informasi ini biasanya dikumpulkan selama dokumentasi kredit (Kithinji, 2010).

\section{Loan to Deposit Ratio}

Menurut Kasmir (2014:225) LDR (Loan to Deposit Ratio) adalah rasio yang digunakan untuk mengukur komposisi jumlah kredit yang diberikan dibandingkan dengan jumlah dana masyarakat dan modal sendiri yang digunakan. Tujuan perhitungan LDR untuk mengetahui dan menilai sejauh mana kondisi kesehatan lembaga perLPDan dalam menjalankan operasional atau kegiatan usahanya. LDR digunakan sebagai suatu indikator untuk mengetahui tingkat kerawanan suatu LPD. 


\section{BOPO}

Rasio BOPO adalah perbandingan antara beban operasional dengan pendapatan operasional dalam mengukur tingkat efesiensi dan kemampuan bank dalam melakukan kegiatan operasinya. Semakin kecil rasio BOPO akan lebih baik, karena bank yang bersangkutan dapat menutup beban operasional dengan pendapatan operasionalnya (Rivai dkk, 2013:480).

\section{HIPOTESIS}

\section{Pengaruh Cash Turnover Terhadap Profitabilitas}

Perputaran kas (cash turnover) adalah perbandingan antara penjualan dengan jumlah kas rata-rata". Jumlah kas dapat pula dihubungkan dengan jumlah penjualan atau salesnya (Riyanto, 2011 : 95). Sujana dan Mustanda (2014) menyatakan bahwa cash turnover berpengaruh positif terhadap ptrofitabilitas. Noviyanty (2016) juga menyatakan bahwa perputaran kas berpengaruh positif signifikan terhadap profitabilitas. $\mathrm{H}_{1}$ : Cash turnnover berpengaruh positif terhadap profitabilitas LPD di Kabupaten Badung

\section{Pengaruh Risiko Kredit Terhadap Profitabilitas}

Pemberian kredit merupakan penghasilan terbesar dalam suatu lembaga keuangan karena merupakan faktor yang penting bagi LPD untuk meningkatkan profitabilitas perusahaan. Surat Edaran Bank Indonesia No.13/24/DPNP/2011 menyatakan bahwa risiko kredit adalah risiko akibat kegagalan debitur dan/atau pihak lain dalam memenuhi kewajiban kepada Bank. Risiko kredit merupakan risiko yang wajar terjadi mengingat salah satu usaha inti bank itu sendiri adalah pemberian kredit. Semakin tinggi risiko kredit pada LPD menunjukan LPD tidak sehat. Ariani dan Ardiana(2015) menyatakan bahwa risiko kredit berpengaruh negatif terhadap profitabiitas. Agung dan Darmayanti (2015) juga menyatakan bahwa risiko kredit berpengaruh negatif terhadap profitabilitas.

$\mathrm{H}_{2}$ : Risiko kredit berpengaruh negatif terhadap profitabilitas LPD di Kabupaten Badung 


\section{Pengaruh Loan To Deposit Ratio Terhadap Profitabilitas}

LDR menunjukan kemampuan LPD dalam menyalurkan dana pihak ketiga yang dihimpun LPD, sehingga berpengaruh terhadap profitabilitas LPD. LDR (Loan to Deposit Ratio) adalah rasio yang digunakan untuk mengukur komposisi jumlah kredit yang diberikan dibandingkan dengan jumlah dana masyarakat dan modal sendiri yang digunakan (Kasmir, 2014:225). Sujana dan Mustanda (2014) menyatakan bahwa loan to deposit ratio berpengaruh positif terhadap profitabilitas. Lestari dan Suartana (2017) juga menyatakan bahwa loan to deposit ratio berpengaruh positif signifikan terhadap profitabilitas.

$\mathrm{H}_{3}$ : Loan to deposit ratio berpengaruh positif terhadap profitabilitas LPD di Kabupaten Badung.

\section{Pengaruh BOPO Terhadap Profitabilitas}

Biaya operasional pendapatan operasional menunjukkan tingkat efisiensi LPD dalam menjalankan operasionalnya. BOPO merupakan perbandingan antara total biaya dan total pendapatan operasional (Sudiyanto, 2010). Semakin rendah tingkat rasio BOPO maka semakin baik kinerja manajemen LPD, sehingga dapat membuat pengeluaran beban biaya menjadi lebih efisien. Semakin tinggi rasio BOPO menunjukkan kinerja manajemen LPD kurang baik, sehingga pengeluaran biaya operasional menjadi tinggi maka profitabilitas LPD menurun. Fajari dan Sunarto (2017) menyatakan bahwa BOPO berpengaruh negatif terhadap profitabilitas. Putri dan Dewi (2017) menyatakan bahwa BOPO berpengaruh negatif terhadap profitabilitas. Lestari dan Suartana (2017) juga menyatakan bahwa BOPO berpengaruh negatif terhadap profitabilitas.

$\mathrm{H}_{4}$ : BOPO berpengaruh negatif terhadap profitabilitas LPD di Kabupaten Badung.

\section{METODE PENELITIAN}

\section{Populasi dan Sampel}

Populasi dalam penelitian ini adalah LPD di Kabupaten Badung yang terdaftar pada LPLPD berjumlah 122 LPD. Sampel yang digunakan dalam penelitian ini dipilih dengan menggunakan metode purposive sampling. Menurut Sugiyono (2013:116) metode purposive sampling adalah teknik penentuan sampel dengan pertimbangan 
tertentu. Sampel dalam penelitian ini berjumlah $102 \mathrm{LPD}$, dengan periode penelitian 3 tahun jumlah keseluruhan sampel dalam penelitian ini berjumlah 306.

\section{Teknik Analisis Data}

\section{Analisis Regresi Linear Berganda}

Analisis regresi linear berganda digunakan untuk mengetahui pengaruh cash turnover, risiko kredit loan to deposit ratio dan biaya operasional pendapatan operasional terhadap profitabilitas pada LPD di Kabupaten Badung digunakan persamaan regresi linier berganda untuk memecahkan rumusan masalah yang ada, yaitu untuk mengetahui pengaruh variabel bebas terhadap variabel terikat. Dalam penelitian ini digunakan analisis regresi linier berganda yang diproses dengan bantuan program SPSS 13.0 for windows. Persamaan regresi linier berganda ditunjukkan sebagai berikut:

$$
R O A=\alpha+\beta_{1} C T+\beta_{2} R K+\beta_{3} L D R+\beta_{4} B O P O+e \ldots \ldots \ldots \ldots . .(1)
$$

\section{HASIL DAN PEMBAHASAN}

\section{Uji Statistik Deskriptif}

Berdasarkan hasil uji statistik deskriptif dapat dijelaskan sebagai berikut :

1. Variabel cash turnover (CT) memiliki nilai minimum sebesar 1,15 nilai maksimum sebesar 315,19 , nilai rata-rata sebesar 17,9420 dan standar deviasi sebesar 27,10824.

2. Variabel risiko kredit (RK) memiliki nilai minimum sebesar 0,53 nilai maksimum sebesar 61,63 , nilai rata-rata sebesar 12,9333 dan standar deviasi sebesar 11,19073.

3. Variabel loan to deposit ratio (LDR) memiliki nilai minimum sebesar 22,14 nilai maksimum sebesar 98,43, nilai rata-rata sebesar 70,4348 dan standar deviasi sebesar 13,37404 .

4. Variabel bopo (BOPO) memiliki nilai minimum sebesar 38,86 nilai maksimum sebesar 124,17, nilai rata-rata sebesar 74,1255 dan standar deviasi sebesar 9,19538.

5. Variabel profitabilitas (ROA) memiliki nilai minimum sebesar 0,85 nilai maksimim sebesar 47,79, nilai rata-rata sebesar 3,6181 dan standar deviasi 2,96439. 


\section{Uji Asumsi Klasik}

\section{Uji normalitas}

Nilai kolmogorov-smirnov $Z$ sebesar 1,305 sedangkan nilai Asymp. Sig. (2tailed) sebesar 0,066. Hal ini menunjukkan bahwa residual berdistribusi normal karena nilai Asymp. Sig. (2-tailed) lebih besar dari 0,05.

\section{Uji multikolinieritas}

Nilai tolerance $\geq 0,1$ dan nilai VIF $\leq 10$, maka dapat disimpulkan bahwa dalam model regresi tidak terjadi gejala multikolinieritas antara variabel bebas.

\section{Uji autokorelasi}

Nilai Durbin-Watson berada pada du $<\mathrm{dw}<(4-\mathrm{du})$ atau $1,8094<1,939<$ 2,1906. Hal ini menunjukkan bahwa dalam model regresi tidak terjadi autokorelasi.

\section{Uji heteroskedastisitas}

Model regresi tidak terjadi gejala heteroskedastisitas. Hal ini karena nilai signifikansi lebih besar dari 0,05 .

\section{Analisis Regresi Linear Berganda}

Persamaan regresi linier berganda sebagai berikut :

$$
\text { ROA }=13,009-0,005 C T-0,014 R K+0,030 L D R-0,152 B O P O
$$

Persamaan tersebut dapat diinterpretasikan sebagai berikut :

1. Nilai koefisien konstanta sebesar 13,009. Hal ini berarti jika cash turnover (CT), risiko kredit (RK), loan to deposit ratio (LDR) dan biaya operasional pendapatan operasional sama dengan nol maka nilai profitabilitas (ROA) sebesar 13,009.

2. Nilai koefisien regresi cash turnover (CT) sebesar -0,005, nilai Signifikansi sebesar 0,374 lebih besar dari 0,05 sehingga cash turnover (CT) tidak berpengaruh terhadap profitabilitas (Y).

3. Nilai koefisien regresi risiko kredit (RK) sebesar -0,014 nilai Signifikansi sebesar 0,280 lebih besar dari 0,05 sehingga risiko kredit (RK) tidak berpengaruh terhadap profitabilitas (Y). 
4. Nilai koefisien regresi loan to deposit ratio (LDR) sebesar 0,030 hal ini berarti bahwa jika loan to deposit ratio (LDR) bertambah satu satuan maka profitabilitas (ROA) akan meningkat sebesar 0,030 dengan asumsi variabel lain konstan.

5. Nilai koefisien regresi bopo (BOPO) sebesar $-0,152$ hal ini berarti bahwa jika bopo (BOPO) bertambah satu satuan maka profitabilitas akan menurun sebesar 0,152 dengan asumsi variabel lain konstan.

\section{Uji Kelayakan Model}

\section{Koefisien Determinasi (Adjusted $\boldsymbol{R}^{2}$ )}

Variabel profitabilitas (ROA) dipengaruhi oleh variabel cash turnover, risiko kredit, loan to deposit ratio dan biaya operasional pendapatan operasional sebesar 23,1 persen. Sisanya 76,9 persen dipengaruhi oleh faktor - faktor lain diluar model regresi.

\section{Uji F}

Nilai signifikansi sebesar 0,000 lebih kecil dari 0,05. Hal ini berarti semua variabel independen (CT, RK, LDR, BOPO) berpengaruh secara serempak terhadap ROA.

\section{Uji t}

Berdasarkan pengujian dapat dijelaskan bahwa :

1. Variabel cash turnover (CT) menunjukkan nilai koefisien regresi sebesar -0,005,

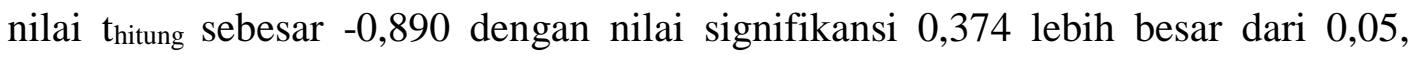
sehingga cash turnover (CT) tidak berpengaruh terhadap profitabilitas (ROA). Hal ini berarti hipotesis pertama $\left(\mathrm{H}_{1}\right)$ ditolak.

2. Variabel risiko kredit (RK) menunjukkan nilai koefisien regresi sebesar $-0,014$ ,nilai thitung sebesar -1,082 dengan nilai signifikansi 0,280 lebih besar dari 0,05, sehingga risiko kredit (RK) tidak berpengaruh terhadap profitabilitas (ROA). Hal ini berarti hipotesis kedua $\left(\mathrm{H}_{2}\right)$ ditolak.

3. Variabel loan to deposit ratio (LDR) menunjukkan nilai koefisien regresi sebesar 0,030 , nilai $t_{\text {hitung }}$ sebesar 2,720 dengan nilai signifikansi 0,007 lebih kecil dari 0,05, sehingga loan to deposit ratio (LDR) berpengaruh positif terhadap profitabilitas (ROA). Hal ini berarti hipotesis ketiga $\left(\mathrm{H}_{3}\right)$ diterima. 
4. Variabel bopo (BOPO) menunjukkan nilai koefisien regresi sebesar $-0,152$, nilai $t_{\text {hitung }}$ sebesar -9,353 dengan nilai signifikansi 0,000 lebih kecil dari 0,05, sehingga bopo (BOPO) berpengaruh negatif terhadap profitabilitas (ROA). Hal ini berarti hipotesis keempat $\left(\mathrm{H}_{4}\right)$ diterima.

\section{Pembahasan Hasil Penelitian}

\section{Pengaruh Cash Turnover Terhadap Profitabilitas}

Hasil penelitian menunjukkan bahwa pihak manajemen LPD kurang efektif dalam mengelola kas yang dimiliki, sehingga perputaran kas yang terjadi diperusahaan menunjukan perputaran yang naik turun, adanya piutang tak tertagih juga mengakibatkan pihak LPD harus menutupi kerugian dari piutang tak tertagih. Sehingga perputaran kas yang terjadi tidak menghasilkan keuntungan dalam waktu cepat. Perputaran kas yang rendah tidak mencerminkan adanya over invesment atau kelebihan kas yang dimiliki LPD yang menunjukkan efisiensi penggunaan kas kurang maksimal. Sehingga cash turnover tidak berpengaruh terhadap profitabilitas LPD di Kabupaten Badung.

\section{Pengaruh Risiko Kredit Terhadap Profitabilitas}

Hasil penelitian menunjukkan bahwa pihak Lembaga Perkreditan Desa lebih berhati-hati dalam menjaga risiko kegagalan kredit yang mengakibatkan jumlah dana yang dimiliki LPD tidak direalisasikan dengan baik, sehingga besarnya dana yang menganggur tidak dapat disalurkan dalam bentuk kredit yang memberikan pendapatan bagi pihak LPD. Tingginya kredit macet mengakibatkan pihak manajemen LPD enggan untuk menyalurkan kreditnya, karena pihak manajmen harus menyiapkan cadangan penghapusan yang besar. Besarnya risiko kredit menjadi suatu penghambat dalam penyaluran kredit. Sehingga risiko kredit tidak berpengaruh terhadap profitabilitas LPD di Kabupaten Badung.

\section{Pengaruh Loan To Deposit Ratio Terhadap Profitabilitas}

Hasil penelitian menunjukkan bahwa pihak manajemen LPD efektif dalam melakukan penyaluran kredit. Semakin tinggi LDR maka pemberian kredit juga akan tinggi sehingga profitabilitas LPD akan meningkat. Hal ini dikarenakan pihak LPD akan 
memperoleh laba dari pemberian kredit yang dilakukan. Berdasarkan data yang diperoleh dalam penelitian ini terlihat bahwa pihak manajemen telah efektif dalam menyalurkan dana pihak ketiga serta modal yang dimiliki maka akan berdampak tehadap kenaikan profitabilitas LPD, sehingga loan to deposit ratio berpengaruh positif terhadap prifitabilitas LPD di Kabupaten Badung.

\section{Pengaruh BOPO Terhadap Profitabilitas}

Hasil penelitian menunjukkan bahwa pihak manajemen LPD kurang efisien dalam mengelola sumber daya yang dimiliki, karena semakin tinggi BOPO maka profitabilitas LPD menurun. Berdasarkan data yang diperoleh dalam penelitian ini menunjukkan bahwa pengeluaran biaya operasional lebih tinggi daripada pendapatan operasional yang diperoleh, sehingga profitabilitas LPD menurun. Pada penelitian ini dapat dinyatakan bahwa BOPO berpengaruh negatif terhadap profitabilitas LPD di Kabupaten Badung.

\section{KESIMPULAN DAN SARAN}

\section{Kesimpulan}

Berdasarkan rumusan masalah, hasil analisis dan pembahasan dapat diambil kesimpulan sebagai berikut:

1. Cash turnover tidak berpengaruh terhadap profitabilitas LPD di Kabupaten Badung.

2. Risiko kredit tidak berpengaruh terhadap profitabilitas LPD di Kabupaten Badung.

3. Loan to deposit ratio berpengaruh positif terhadap profitabilitas LPD di Kabupaten Badung.

4. BOPO berpengaruh negatif terhadap profitabilitas LPD di Kabupaten Badung.

\section{Saran}

Berdasarkan hasil pembahasan dan kesimpulan, dapat diberikan saran yaitu Manajemen LPD di Kabupaten Badung diharapkan agar lebih efisien dalam mengelola biaya operasional agar pengeluaran pada LPD lebih rendah daripada pendapatan operasionalnya. Untuk peneliti selanjutnya diharapkan dapat melakukan penelitian pada ruang lingkup penelitian yang lebih luas, serta dapat menguji variabel diluar penelitian 
ini seperti variabel Capital Adequacy Ratio (CAR), Leverage serta Total Asset Turnover.

\section{DAFTAR PUSTAKA}

Ariani dan Ardiana. 2015. Pengaruh Kecukupan Modal Tingkat Efisiensi Risiko Kredit dan Likuiditas pada Profitabilitas LPD Kabupaten Badung. E-Jurnal Akuntansi Universitas Udayana.

Brigham, E. F., dan J. F. Houston. 2011. Manajemen Keuangan. Edisi Bahasa Indonesia. Jakarta: Erlangga.

Darmayanti dan Agung. 2015. Pengaruh Risiko Kredit Likuiditas Kecukupan Modal Dan Efisiensi Oprasional Terhadap Profitabilitas Pada PT BPD Bali. E-Jurnal Akuntansi Universitas Udayana.

Fahmi, Irham. 2012. Analisis Laporan Keuangan. Cetakan Ke-2. Bandung: Alfabeta.

Fajari dan Sunarto. 2017. Pengaruh CAR LDR NPL BOPO Terhadap Profitabilitas Bank (Studi Kasus Perusahaan Perbankan Yang Tercatat Di Bursa Efek Indonesia Periode Tahun 2011-2015). Prosiding Seminar Nasional Multi Disiplin Ilmu \& Call For Papers Unisbank ke-3.

Ghozali, Imam. 2016. Aplikasi Analisis Multivariete Dengan Program (IBM SPSS). Edisi 8. Badan Penerbit Universitas Diponegoro. Semarang.

Kasmir. 2014. Analisis Laporan Keuangan. Edisi Satu. Cetakan Ketujuh. Jakarta : PT Raja Grafindo Persada.

Kasmir. 2015. Analisis Laporan Keuangan. Jakarta : PT Raja Grafindo Persada.

Kithinji, Angela M. 2010. Credit Risk Management and Profitability of Commercial Banks in Kenya, School of Business, University of Nairobi.

Lestari dan Suartana. 2017. Pengaruh Tingkat Efisiensi, Risiko Kredit, Tingkat Peyaluran Kredit Pada Profitabilitas LPD. E-Jurnal Akuntansi Universitas Udayana.

Munawir, S. 2010, Analisa Laporan Keuangan. Edisi 4. Liberty, Yogyakarta : BPFE.

Narayana, Gede. 2013. Pengaruh Perputaran Kas Loan To Deposit Ratio Tingkat Permodalan dan Leverage Terhadap Profitabilitas BPR Se-kota Denpasar Periode 2009-2011. E-Jurnal Akuntansi Universitas Udayana.

Novianty, Dita. 2016. Pengaruh Risiko Kredit, Perputaran Kas Dan Tingkat Kecukupan Modal Terhadap Profitabilitas Pada Perusahaan Perbankan Yang Terdaftar Di BEI Periode 2012-2014. E-Jurnal Akuntansi Universitas Lampung.

Peraturan Gubernur Bali Nomor 11 Tahun 2013 Tentang Lembaga Perkreditan Desa. 
Putra, Gde Bagus Brahma Putra dan Yuliastuti, Ida Ayu Nyoman. 2019. Kemampuan Menghasilkan Keuntungan Usaha Mikro Kecil Menengah di Kota Denpasar dan Faktor-faktor yang Mempengaruhinya. Jurnal Riset Akuntansi. Vol 9, No. 1, Hal $37-47$

Putri, Subagiono dan Dewi Sutrisna. 2017. Pengaruh LDR CAR NPL BOPO Terhadap Profitabilitas LPD di Kota Denpasar. E-Jurnal Manajemen Unud.

Riyanto, Bambang. 2011. Dasar-dasar Pembelanjaan Perusahaan. Yogyakarta : BPFE.

Sari, Ni Luh Putu Ayu Yunia; Sunarsih, Ni Made; dan Yuliastuti, Ida Ayu Nyoman. 2019. Pengaruh Profitabilitas, Ukuran Perusahaan, Struktur Aktiva, dan Likuiditas Terhadap Struktur Modal. Jurnal Seminar Nasional Inovasi dalam Penelitian Sains, Teknologi dan Humaniora

Sartono, Agus. 2010. Manajemen Keuangan. Edisi Ketiga.Yogyakarta : BPFE

Sudana, Made. 2011. Manajemen Keuangan Perusahaan Teori dan Praktek. Jakarta: Erlangga.

Sudiyatno, Bambang. 2010. Analisis Pengaruh Dana Pihak Ketiga, BOPO, CAR dan LDR Terhadap Kinerja Keuangan pada Sektor Perbankan yang Go Public di Bursa Efek Indonesia. Jurnal Dinamika Keuangan dan Perbankan, ISSN: 19791878.

Sugiyono. 2013. Metode Penelitian Pendidikan Pendekatan Kuantitatif, Kualitatif dan $R \& D$. Bandung: Alfabeta.

Sugiyono. 2015. Metode Penelitian Kuantitatif Kualitatif R\&B. Bandung : Alfabeta.

Sujana dan Mustanda. 2014. Pengaruh Cash Turnover Loan to Deposit Ratio Capital Adquacy ratio dan Dana Pihak Ketiga terhadap Profitabilitas LPD. Jurnal Ekonomi dan Bisnis Universitas Udayana.

Surat Edaran Bank Indonesia No.13/24/DPNP/2011

Susandya, Anak Agung Putu Gede Bagus Arie dan Yuliastuti, Ida Ayu Nyoman. 2019. Analisis Profitabilitas BPR Lestari Pasca Akuisisi. Accounting Global Journal. Vol. 3, No. 2, Hal 138-144

Taswan. 2010. Manajemen Perbankan. Konsep, Teknik dan Aplikasi. Yogyakarta: UPP STIM YKPN.

Yanti dan Suryantini. 2015. Pengaruh Dana Pihak Ketiga Kecukupan Modal Risiko Kredit dan Likuiditas Terhadap Profitabilitas LPD Kabupaten Badung. E-Jurnal Manajemen Unud. 
Veitthzal Rivai. 2013. Credit Management Handbook Manajemen Perkreditan Cara Cara Mudah Menganalisa Kredit. Jakarta: Rajagrafindo Persada.

Yuliastuti, Ida Ayu Nyoman dan Dewi, Ni Luh Putu Sandrya. 2017. Analisis Efektivitas dan Kontribusi Retribusi Daerah terhadap Pendapatan Asli Daerah (PAD) Kota Denpasar. Jurnal Riset Akuntansi. Vol 7. No. 1. Hal 91-102 